\title{
Aspectos teóricos en relación a la estimulación multisensorial en pacientes comprometidos de conciencia
}

Fernández Orellana, M. Cristina

\begin{abstract}
- Resumen
La Escuela de Terapia Ocupacional de la Universidad de Chile, en el contexto del Programa Ayudante Alumno elabora un Programa de Estimulación Temprana para pacientes comprometidos de conciencia en estados de sopor o coma, con el fin de realizar una investigación que permita analizar y comparar las respuestas observadas en ellos, frente a estímulos sensoriales personalizados, que son aportados por un familiar cercano como elementos significativos para el paciente. En este documento se analizan algunos aspectos teóricos relacionados con la problemática de los pacientes, Neurociencia, actividad terapéutica y Terapia Ocupacional que fundamentan esta propuesta.
\end{abstract}

\begin{abstract}
The School of Occupational Therapy of the University from Chile, in the Assistantship Student Program instance development a Program of Early Estimulation for the committed patients of conscience in states of sleepiness or coma, as a result of an accident vascular or a traumatism cranial, whit the intention to investigate, to analyze and to compare the answer observadas front stimulation personalized based on antecedents that a near relative contributes by your family as significant for the patients. In this document sorne theoretical aspects related with the problem of the patients are analyzed, neurociencia, therapeutic activity and Occupational Therapy that base are proposed.
\end{abstract}

